\title{
THE TENSION BETWEEN MILITARISATION AND DEMOCRATISATION IN WEST AFRICA A Comparative Analysis of Niger and Guinea
} Khabele Matlosa and David Dossou Zounmenou

\author{
Khabele Matlosa is Programme Advisor, UNDP / ECA Governance Initiatives, \\ Addis Ababa, Ethiopia \\ email: khabele.matlosa@undp.org
}

\begin{abstract}
While there has been some progress in West Africa towards shedding the dark history of militarism that spanned the 1960s-1980s and embracing democratisation, militarism still lingers, remaining a ghost that has haunted the democracy project that began in the region in the 1990s. Thus, West Africa has faced enormous challenges in its quest for democratisation. One of the biggest of these has been the militarisation of politics and of society at large. This problem persists even today, after encouraging progress towards democratisation in the past two decades. Two countries in the region that epitomise this recurring tension between militarisation and democratisation are undoubtedly Niger and Guinea. Both of them manifest the consequences of a governance deficit and the problems of democratic transition in which the military continues to play a dominant role. This chapter examines critically the tension between militarisation and democratisation in West Africa in general, with specific focus on Niger and Guinea. In an attempt to provide a comparative analysis of the two cases the chapter assesses progress made, highlights existing challenges and draws lessons that might be relevant for other African countries.
\end{abstract}

\section{INTRODUCTION}

There is no gainsaying the fact that Africa has made enormous progress in embracing multiparty democracy, especially since the 1990s, with the end of the Cold War. This progress was not only a by-product of the fall of the Berlin Wall in 1989 it was also a direct response to internal popular pressures mounted against dictatorial regimes, most of which were military. 
Despite the region's advance towards democratisation militarism still occasionally emerges, reminding us that democracy in Africa is a work in progress, and is continuously under construction and reconstruction. This stark reality requires transformative and visionary leadership if multiparty politics and participatory democracy are to be institutionalised and entrenched on a sustainable basis. With this as a backdrop this chapter grapples with tensions between militarism and democratisation in West Africa through a comparative analysis of the recent experiences of Niger and Guinea.

The chapter examines critically the tension between militarisation and democratisation in West Africa in general, specifically focusing on Niger and Guinea, in an attempt to provide a comparative analysis of the two cases. It is divided into several sections. The second section provides a contextual background, setting the stage for the subsequent discussion; the third presents an historical overview of the military in politics in Africa; the fourth unveils the uncertain transitions in Niger and Guinea; the fifth assesses the extent to which recent electoral processes demonstrate some form of demilitarisation of politics in the two countries. The sixth section distils some lessons other African countries might learn from recent developments in Guinea and Niger. The conclusion wraps up the debate, highlighting our main observations.

One thing that is certain is that both Guinea and Niger remain fragile democratic experiments and there is still the possibility of democratic reversal and relapse into militarism. To avoid this possible reversal there is a need to build and enhance robust institutions, leadership and far-reaching security sector reforms.

\section{THE MILITARY IN AFRICA: AN OVERVIEW}

The post-colonial political trajectory of African states reveals a complex web of civil-military relations and, by extension, political power and its legitimacy. A majority of African countries achieved their political independence on a silver platter, through negotiations involving African nationalists and colonial administrations. The newly independent states were then ushered through immediate post-independence elections to choose their first national leaders.

In other cases independence was achieved through protracted armed liberation struggles which also, in some instances, led to the colonial administrations being defeated and giving way to nationalist leaders who assumed state power. In some cases liberation struggles did not lead to outright military victory but to a negotiated settlement of the armed conflict.

Irrespective of the transition trajectory from colonial rule to independence it soon became evident that the legitimacy of some new governments moved 
from the will of the people to the barrel of a gun as one country after another experienced military coups. The military became a power unto itself. This trend manifested in a spate of coups d'état, especially between the mid-1960s and the late 1980s. This development triggered an enormous amount of pessimism about the feasibility of democracy in Africa.

The involvement of the army in national politics in Africa in general and West Africa in particular was not an historical accident. It had its structural roots in colonialism itself, whose authority was predicated upon conquest, coercion and violence in which the security forces were systematically used to impose foreign domination on the African people, who were considered to be colonial subjects (Mbembe 1990, p 375).

Under colonial rule the military was an instrument of social and political oppression and repression. Upon independence African states inherited weak state apparatuses predicated upon military repression and, in many senses, detached from the people. In many countries post-independence leaders failed to transform the state by, for instance, developing with their people a 'social contract' that might have served as a basis of state legitimacy and sustainable democratic governance. In a word, the necessity for political survival compelled most leaders to manipulate the army or to be manipulated by it (Bangoura 1992; Coleman \& Brice 2005; Collier 2009).

While in theory new national armies were created in independent Africa to ensure defence and territorial integrity and to contribute to the nation-building project, in practice the military has evolved to play other roles, including involvement in partisan politics. Thus, a few years into self-government Africa became a theatre of military coups in which governance by the bullet took centre stage, postponing democratisation and jettisoning rule by the ballot.

It all began in 1963 when the elected governments of Togo (13 January), Congo-Brazzaville (15 April) and Dahomey, Benin (23 October) were toppled in the first post-independence military coups on the continent. It is no wonder, therefore, that between the 1960s and the 1980s more than 50 successful coups, 56 attempted coups and 102 alleged military plots took place in no fewer than 45 countries on the continent (Kieh \& Agbese 2005; Collier 2005; Souare 2006). By the end of the 1980s close to 60 successful military coups had been staged and most of the 54 existing African states had experienced at least one coup or related incident. By 2010 there had been 81 successful military coups in Africa, the majority of which took place in West Africa. Table 1 provides a vivid illustration of successful coups d'état on the continent between 1958 and 2010.

As Table 1 shows there was a steady decrease in the number of military coups in Africa in the late 20th century. However, between 2000 and 2010 five coups (Togo in 2005; Mauritania in 2007 \& 2009; Guinea Conakry in 2008; and Niger 
in 2010) either interrupted a transition to democracy or prevented a democratic transfer of power. West Africa, which has had the highest number of coups, not only in each decade but also overall, accounts for more than 55 per cent of coups on the continent.

Table 1

Successful coups d'état in Africa: 1958-2010

\begin{tabular}{|c|c|c|c|}
\hline Region & Country & Year & Total \\
\hline \multirow[t]{13}{*}{ West Africa } & Benin & 1963, 1965 (2), 1967, 1969, 1972 & 6 \\
\hline & Burkina Faso & $1980,1982,1983,1987$ & 4 \\
\hline & Côte d'Ivoire & 1999 & 1 \\
\hline & Gambia (The) & 1994 & 1 \\
\hline & Ghana & $1966,1972,1978,1979,1981$ & 5 \\
\hline & Guinea & 1984,2008 & 2 \\
\hline & Guinea Bissau & 1980,2003 & 2 \\
\hline & Liberia & 1980 & 1 \\
\hline & Mali & 1968,1991 & 2 \\
\hline & Niger & $1974,1996,1999,2010$ & 4 \\
\hline & Nigeria & 1966 (2), 1975, 1983, 1985, 1993 & 6 \\
\hline & Sierra Leone & $1967,1968,1992,1997$ & 4 \\
\hline & Togo & 1963, 1967, 2005 & 3 \\
\hline \multirow[t]{7}{*}{ Central Africa } & Burundi & $1966(2), 1976,1987,1996$ & 5 \\
\hline & $\begin{array}{l}\text { Central African } \\
\text { Republic }\end{array}$ & 1966, 1979, 1981, 2003 & 4 \\
\hline & Chad & $1975,1979,1990$ & 3 \\
\hline & Congo-Brazzaville & 1968,1999 & 2 \\
\hline & $\begin{array}{l}\text { Democratic Republic } \\
\text { of Congo }\end{array}$ & 1965,1994 & 2 \\
\hline & Equatorial Guinea & 1979 & 1 \\
\hline & Rwanda & 1973 & 1 \\
\hline \multirow[t]{3}{*}{ East Africa } & Somalia & 1969 & 1 \\
\hline & Sudan & $1958,1969,1985,1989$ & 4 \\
\hline & Uganda & 1966, 1971, 1979, 1980, 1985, 1986 & 6 \\
\hline Southern Africa & $\begin{array}{l}\text { Lesotho } \\
\text { Madagascar }\end{array}$ & $\begin{array}{l}1986,1991 \\
1975,2009\end{array}$ & $\begin{array}{l}2 \\
2 \\
\end{array}$ \\
\hline \multirow[t]{4}{*}{ North Africa } & Algeria & 1965 & 1 \\
\hline & Libya & 1969 & 1 \\
\hline & Mauritania & $1978,1984,2005,2009$ & 4 \\
\hline & Tunisia & 1987 & 1 \\
\hline Total & & & 81 \\
\hline
\end{tabular}

Source: Adapted from Souare 2006; ISS, African Security Review 2010 
Most of these have occurred in Francophone Africa, although two former British colonies, namely Ghana and Nigeria, have also had their own (un)fair share of post-independence militarism. West Africa experienced four major civil armed conflicts, with disastrous consequences for the region. These were Liberia (1989), Sierra Leone (1992), Guinea-Bissau (1998) and Côte d'Ivoire (2002). Among the most visible impacts of such conflicts are the proliferation of light weapons and the militarisation of society, as well as the undesirable phenomenon of child soldiers.

Evidence suggests that, in comparison, Southern Africa has not been as prone to coups d'état as other regions of the continent. Of the 14 states that constitute the Southern African Development Community (SADC) only two have experienced military coups, namely, Lesotho in 1986 and 1991 (see Matlosa 1998) and Madagascar in 1975 and 2009.

In East Africa only Tanzania and Kenya have been immune to the cancer of militarism and have never experienced military coups. This cancer has afflicted the political systems of three countries in this region, namely Somalia, Sudan and Uganda. In fact, in Uganda, military coups were so frequent they began to seem like annual festivals (1979 \& 1980; 1985 \& 1986). Like West Africa, Central Africa has been an epicentre of military coups. All but one Central African state (Gabon) have experienced at least one coup since independence.

A plethora of literature on the military in Africa (Deger 1986; Decalo 1976; Hutchful \& Bathily 1998; McGowan 1984; Collier 2005; Souare 2006) offers some insights into the main driving forces behind coups on the continent. One of these is that the army was the only organised structure able to maintain order given the supposed inability of the civilian authorities to do so.

According to Omoigui (2004, p 5):

The military has an unrivalled capacity to project force. This makes it an important tool for asserting state authority, enforcing the rule of law, and protecting the nation against external aggression. Unfortunately, such power, if not properly managed, can also pose a serious threat against civil authority as has been demonstrated numerous times in several African countries.

The deterioration of the socio-political and economic environment has, on many occasions, served as a rationale for coups, while ideological rivalries and elite power struggles could also well feature among the explanatory variables. Even though many coups took place amid domestic tensions, external factors could not be excluded, particularly given the context of the Cold War.

A multiplicity of explanatory factors notwithstanding there is no gainsaying 
that the involvement of the military in politics has transformed systematic violence into a mode of power alternation and change of leadership in Africa, with three main consequences. Firstly, the partisan intervention of the military in the national polity has severely undermined the consolidation of the state-building process based on the rule of law and sustainable democratic governance. Secondly, bad governance and the autocracy generally associated with military rule drove leaders further away from the people and their aspirations. Thirdly, military expenses contributed to the failure to invest in the more productive sectors vital for sustainable human development.

As a result of coups, argues Ali Mazrui (1996, p 177), 'power no longer belongs to those who own the means of production but is confined in the hands of the military officers who controlled the means of destruction'. The experience of military intervention in politics in Africa has shown that military coups hardly serve as a foundation stone for democratisation. If anything, they are the very antithesis of democracy.

Africa has had almost two decades of democratic experience since the end of the Cold War. In essence, political systems based on democratic norms have become more salient on the continent. Many African countries have embraced a culture of regular multiparty elections, their quality notwithstanding. Many have also established democratic institutions of varying degrees of effectiveness. These countries have also put in place institutional, constitutional and legal mechanisms for orderly civil-military relations, as well as civil control over the armed forces. Some have seen a peaceful transfer of power from one elected regime to another. However, for others, the military still remains a power broker in the national polity, if not a power unto itself in control of the state.

Electoral violence has become a serious threat to political stability and genuine democratisation (AUC 2010; Matlosa, Khadiagala \& Shale 2010). In fact, many countries in Africa are still locked in a transition, with uncertain outcomes, or, what Sorensen (2010) terms 'democratic stand-still'. Some leaders, both military and civilian, continue to resist democracy as a political system, perceiving it as a threat to their survival and interests. As Muhlberger \& Paine (2000, p 3) poignantly observe,

democracy appears both as a symbol of hope and a cause for fear. It arouses strong feelings because some see democracy as a way forward to a better future for humanity while others view it as a dangerous delusion, or a threat to their own privileges.

Niger and Guinea illustrate the tension between militarisation and democratisation. It is to this subject that we devote the remainder of this article. 


\section{UNCERTAIN TRANSITIONS AND MILITARY COUPS IN NIGER AND GUINEA}

Complicating the democratic transition in Niger, in 1999 its then president, Mamadou Tandja, manipulated the 1999 Constitution in a bid to prolong his hold on power beyond the mandatory two terms. This move triggered a political crisis resulting in a military coup on 18 February 2010 which dislodged Tandja and established the Supreme Council for the Restoration of Democracy.

With Tandja in detention a transitional election was held on 31 January 2011. The run-off poll became a fierce contest between Mahamadou Issoufou of the opposition Parti Nigerien pour la Democracy et le Socialisme (Nigerien Party for Democracy and Socialism - PNDS), and Seyni Oumarou of the ruling Mouvement National pour la Société du Développement (National Movement for the Development of Society - MNSD). Observers judged the election to have been peaceful. Issoufou won, with 58 per cent of the total valid votes, with Oumarou polling a paltry 42 per cent. Oumarou accepted the results and thus, all things being equal, Niger seems poised to outgrow the spiral of instability it has suffered over decades.

Guinea has experienced political instability virtually since independence in 1958. Politics in that country has been marked by factionalism within an illdisciplined army, a deep-rooted culture of impunity, and decades of autocratic rule. Guinea's history has been a stark contrast to the hopes of 1958, when its first leader, Ahmed Sékou Touré, sharply rejected colonial domination in any form.

The country has been dogged by persistent instability punctuated by entrenched autocracy, thus postponing the democratic journey for decades. Guinea is still hemmed in by the tension between militarisation and democratisation. In 2010 general elections were held (first round in July and second round in November). The run-off presidential election pitted Cellou Dalen Diallo against Alpha Condé, resulting in the former winning the poll by about 53 per cent against the latter's 47 per cent. Tensions persisted after the elections as Diallo refused to accept the results, triggering the declaration by the military of a state of emergency.

Armed forces have dominated the political lives of Niger and Guinea since their independence. The military coup of 18 February 2010 in Niger was the culmination of a series of initiatives aimed at undermining the democratisation process. President Tandja's decision, a few months before the end of his second and last term in office, to hold a controversial referendum despite public opposition to this undemocratic move by key institutions (Constitutional Court, Parliament, State Council, all of which were eventually dissolved), civil society organisations and political parties, was seen as a violation of Niger's 1999 Constitution, which, 
like most of those in Africa, limited the presidential mandate to a maximum of two five-year terms. It was also seen as a breach of the country's commitment to respect duly ratified regional norms (Niger was among the first countries to ratify the Economic Community of West African States - ECOWAS's 2001 Additional Protocol on Democracy and Good Governance).

Guinea's citizens initially hailed the military junta that seized power peacefully in the country in December 2008 as a 'liberator'. However, subsequent developments, including the massacre of opposition supporters on 28 September 2009 and an attempt on the life of the junta leader, Moussa Dadis Camara, brought to the fore the challenges of a peaceful post-coup political transition (Souare 2009; Souare \& Handy 2009; Diallo \& Takwa 2008).

The ensuing massacre of civilians and the outcry it caused throughout the region and beyond reminded ECOWAS leaders of the potential security risk posed by unconstitutional regime changes. Almost 200 people were reportedly killed and another 1000 wounded, including many opposition leaders (Human Rights Watch 2009). Some of the bodies were hidden and witnesses lived in fear of being targeted by security forces attempting to undermine any eventual investigation and possible charges of crimes against humanity (Human Rights Watch 2009).

In contrast to Guinea, where the coup was almost expected, Niger's 1999 Constitution has in-built provisions that make it difficult to change. Article 135 of the Constitution provides that two-thirds of the national Parliament must vote in favour of any changes or the proposed changes must be the subject of a referendum. Article 36 contains special provisions regarding the presidential mandate, which may not be modified at all and Article 136 clearly stipulates that 'the Republican State, the multi-party system, the principle of separation of State and religion and the provisions of articles 36 [presidential mandate] and 141 [the amnesty for those responsible for the 1995 and 1999 coups d'état] of the present constitution cannot be the object of any revision' (Constitution of Niger 1999).

Unlike Guinea, whose political transition was delayed until much later, Niger returned to political normality following the assassination in 1999 of President Ibrahim Bare Mainassara. The elected government, led by President Mamadou Tandja, then completed ten years of reforms aimed at achieving political stability based on democratic dispensation.

Tandja ruled with the support of a coalition of political parties that collapsed as a result of sharp disagreements that emerged as soon as he made public his intention to amend the Constitution to allow himself a third term in office. The ensuing fragmentation of the ruling coalition made it difficult to pass the controversial amendment through Parliament. Domestic political actors and regional leaders were puzzled by Tandja's decision to hang on to power after two successful terms that had partially restored economic growth and political 
stability in Niger, raising the prospects for successful democratic transition. But, as with all democratic transitions, there is a significant risk of reversal and leaders and political actors often seek to exploit the weaknesses of the process to remain in control.

While Tandja argued that he needed three more years to complete his 'reforms' opposition leaders believed Niger's problems were too immense to be resolved by a 71-year-old leader in just three additional years. It seemed that Tandja's plan to stay in power indefinitely was motivated more by his own self-serving interests and those of the political elite around him to control state power, which, in turn, was used as a licence for wealth accumulation and political survival.

His motivation for prolonging his stay in state house had little or nothing to do with concerns about national development. Self-preservation loomed larger than national purpose in his constitutional amendment plan. This, in itself, exposed the fragility of the democratisation process in Niger. Lucrative mining contracts signed with various companies, including French uranium giant AREVA ( $\mathrm{a} € 1.2$-bn investment) and China, could shed some light on the problem and the attitude of Tandja's administration (Niger has the second-largest uranium site in the world, with the capacity to produce at least 5000 tons of uranium annually).

Following the rise to power of the junta the commission against economic and financial crime ordered an investigation that revealed that Tandja and some of his collaborators had been involved in financial misappropriation amounting to nearly €98-million over 10 years (Baudais \& Chauzal 2010).

It is clear, however, that beyond the anticipated financial gains from the uranium deals and oil discoveries the fear among Tandja's closest ministers and collaborators of losing access to the privileges of power help make sense of the presidential assault on the Constitution and the institutions that had made such a significant contribution to political stability in the past decade.

Tandja's moves provoked widespread protest and on 25 June 2009 his main supporter, the Convention Démocratique et Sociale (CDS) of former President Mahamane Ousmane, withdrew eight ministers from the government. A concerted opposition emerged and denounced the initiative as an institutional coup d'état. Some 200 political parties and NGOs joined to form the Front pour la Défense de la Démocratie (FDD) as tens of thousands rallied in the capital, Niamey, to challenge Tandja's bid.

The military junta that overthrew Tandja dissolved the government and with it the regime's tailormade 2009 Constitution, in which there was no mention of term limits. The Supreme Council for the Restoration of Democracy (CSRD), as the junta quickly styled itself, appointed a new civilian prime minister, 
Mahamadou Danda, with the task of forming a new government. This largely civilian government was transitional, with the responsibility to take the necessary steps leading up to elections within 18 months.

The various decisions taken by the junta indicated that the transition was initially likely to lead to the return to a new political dispensation favourable to the democratisation process. One of the most reassuring signs was the promise by the junta's leaders and government ministers not to stand in any subsequent elections. A new Constitution and electoral code were developed and the government established an independent electoral commission. It also established a consultative committee, drawn from all parts of society, to assist in the transition process. The new Constitution reinstated the limitation of the presidential mandate and the principle of the separation of powers and upheld the amnesty law for former coup makers.

In Guinea the military coup was the direct result of the failed transition led by a civilian prime minister, Lansana Kouyaté, whose own presidential ambitions compromised the neutrality of the civilian-led transition process.

Kouayaté was appointed in 2007 following ECOWAS's mediated roadmap for neutral transition in Guinea. His inability to steer the process to a successful conclusion partly explained the early popular support enjoyed by the soldiers, which was more of a sign of exasperation caused by the political impasse than an endorsement. But, as was to be anticipated, military coups in Guinea, as elsewhere in Africa, hardly serve the interests of a successful political transition and sustainable democratic order. The coup leader, Captain Moussa Dadis Camara, called his group the Conseil national pour la démocratie et le développement (CNDD) or the National Council for Democracy and Development. Its first move was to announce the dissolution of the government and the National Assembly (Parliament) and suspend the Constitution.

\section{REGIONAL RESPONSES AND THEIR IMPLICATIONS}

ECOWAS has been involved in the political crises in both Niger and Guinea since 2007. In the case of Guinea, its involvement began in earnest when a trade unionled protest was brutally repressed by Lansana Conté's regime. As for Niger, the regional organisation acted as soon as Mamadou Tandja's supporters initiated the so-called 'Tazarche' (continuity), calling on him to remain in power even as he neared the end of his second and last term in office.

The repression of the protests against Tandja threatened the fragile peace in West Africa, where Liberia, Guinea Bissau and Sierra Leone were just emerging from devastating conflicts. ECOWAS undertook a number of initiatives in an attempt to bring about peaceful political transition in Niger and Guinea. 
In Guinea, the initiative of the regional leaders was aimed at creating the framework for negotiations involving the government, political parties and leaders of trade unions. Of particular significance was the mediation led by former president Ibrahim Babangida of Nigeria and the president of the ECOWAS Commission, Mohamed Ibn Chambas. It was under the auspices of ECOWAS that the defunct Transition Road Map had been agreed upon in March 2007, with Lansana Kouyaté appointed prime minister.

As would be the case with Niger in the aftermath of the February 2010 coup, ECOWAS's decision on 10 January 2009 to suspend Guinea's membership but to remain engaged with Moussa Dadis Camara's junta to promote a swift return to constitutional and democratic order was taken in accordance with its existing protocols, notably the 2001 Additional Protocol on Democracy and Good Governance.

However, that approach was not successful with Camara, who wanted to extend his hold on power beyond the transition period, unleashing his repressive machine on the citizens. For ECOWAS what was at stake in Guinea was more than the security of the country's citizens or the stability of state institutions.

Guinea is in the highly volatile Mano River region, consisting of Liberia, Sierra Leone and Côte d'Ivoire, countries facing serious domestic security challenges with potential spillover effects on the wider West African region. The deliberate decision by Camara's forces to open fire on peaceful demonstrators in September, 2009 left more than 100 people dead and thousands wounded. It also demonstrated an entrenched culture of brutality and impunity as well as the threat the army posed not only to the security of the state and its citizens but to the democratisation project in the West African region at large.

Locked in his belief that he was 'the saviour of Niger' President Tandja was determined to hold a referendum on the proposed removal of the term limit so he could retain power beyond 2009. In doing so he paid no heed to calls from opposition parties and civil society leaders and multiple missions from ECOWAS or development partners to refrain from violating his country's Constitution and throwing Niger into unnecessary political turmoil. This was tantamount to reneging on his government's commitment to uphold national and regional norms of democracy and good governance.

The 2001 ECOWAS Additional Protocol on Democracy and Good Governance provides that a substantial electoral law may not be changed without the consent of a large majority of political actors, at least six months before an election. The fact that Tandja held the referendum within the six-month period gave ECOWAS the authority to intervene. Had he called for a referendum two years before his term ended the organisation might, perhaps, not have had the right to act. 
As early as June 2009 the ECOWAS Commission warned that Niger could face sanctions if Tandja went ahead with the referendum. On 21 July, as a preventive measure, a delegation comprising ECOWAS, African Union (AU) and United Nations (UN) representatives went to Niger to reiterate their opposition to the president's bid to manipulate the Constitution.

In addition to the regional efforts, the European Union (EU), a major development partner of Niger, threatened to suspend financial aid, while the United States of America expressed 'deep concerns' over Tandja's attempt to retain power against the will of the people. Ignoring all these concerns the president held both the controversial referendum (on 4 August) and legislative elections (in October), even after the chairman of the Authority of Heads of State and Government of ECOWAS had dispatched a high-powered delegation comprising Liberian President Ellen Johnson-Sirleaf, ECOWAS's Mohamed Ibn Chambas and former Nigerian leader General Abdulsalami Abubakar to persuade the Nigerien leader to postpone the elections to enable the country's political stakeholders to discuss a resolution of the constitutional crisis.

ECOWAS's leaders remained firm, applying the agreed normative and institutional frameworks aimed at promoting democracy, governance and the rule of law among the organisation's member states. They demonstrated political commitment to exhausting all peaceful and diplomatic options available to resolve the constitutional crisis.

The gradual nature of the regional intervention added to the pressure on Tandja's regime to preserve the fragile political order established in the aftermath of the 1999 post-coup transition. The controversial constitution he mooted concentrated power in his hands, removed the term limit and abolished the position of prime minister in order to create an imperial presidency. It also provided for a bicameral legislature with a National Assembly and a Senate, as against the unicameral Parliament created by the 1999 Constitution. Finally, it mandated Tandja to remain in power until December 2012. There is no doubt that this constitutional manipulation would have nipped the Nigerien democratisation process in the bud.

This was the context in which ECOWAS appointed its mediation team to find a consensual solution to the crisis that would 'create an atmosphere conducive to the restoration of democratic governance, the respect for the rule of law and the creation of opportunity for all political actors and the citizenry to participate in the electoral process' (ECOWAS 2009a). The agenda of the mediators was to ensure that all Tanda's controversial initiatives, including the referendum and the new constitution, were reversed through political consensus.

The team soon realised that no progress could be made while Tandja was not prepared to make concessions. His presidential term expired on 22 December 
2009, which made him an institutional 'coup maker'. A proposed plan to maintain him in power while appointing a prime minister from the opposition for a period of transition during which a new constitution would be elaborated and fresh elections held also failed. Although opposition parties found the proposal acceptable, Tandja and his supporters scorned it, a stalemate the army attempted to resolve on 18 February 2010, when a group of military officers seized power in a coup that claimed the lives of at least ten people.

As far as Guinea is concerned it was at the extraordinary session of ECOWAS's Authority of Heads of State and Government held on 17 October 2009 in Abuja that West African leaders 'expressed deep concern over the mass violation of human rights and humanitarian law' in the country and roundly condemned the brutal acts of massacre, rape and other atrocities perpetrated by the security forces against unarmed women and civilians under the authority of the junta on 28 September 2009.

The AU characterised the acts of impunity and the rapidly deteriorating political, security and human rights situation in Guinea as seriously damaging to the democratic process in the country and a real threat to the peace, security and stability of the region (ECOWAS 2009b).

Given the complexity of the political situation Burkina Faso President Blaise Compaore, the ECOWAS mediator, had quite a mountain to climb in his bid to resolve the crisis in Guinea. Regional leaders not only showed strong support for his mediation efforts, they also urged him to take all appropriate steps to reestablish dialogue among the Guinean political actors with the aim of:

- establishing a new transitional authority to ensure a short and peaceful transition to constitutional order through credible, free and fair elections;

- ensuring that the chairman and members of the CNDD, the prime minister and those who hold high office in the new transitional authority would not stand in the forthcoming presidential elections;

- setting up benchmarks in the transition chronogram already agreed and ensuring their timely achievement.

Although the mediator's mandate was clear his first draft proposal, made after consultations with key stakeholders in the country in late December, showed some partiality towards Dadis Camara's junta. Accordingly the plan maintained Camara not only as head of the transitional government but also as supreme chief of the army. The proposal made provision for a prime minister to be appointed from the ranks of the opposition and for a government of national unity. 
As was to be expected the opposition categorically rejected the proposal, which, in their view, 'legitimised' Camara's military junta and ignored the events of 28 September, despite the fact that these events had been condemned by the international community and were under investigation by the International Criminal Court. In addition, they argued that it failed to address the ethnic nature of Camara's political strategy to hang onto power, including the indefensible use of mercenaries. The result, they contended, was that the proposal presented an unthinkable scenario in which the people who, after losing their right to choose their leaders freely when Camara seized power, would now face an extended period of vicious state-sponsored repression.

While discussions were under way to iron out differences Camara was wounded in an assassination attempt and was flown to Morocco for medical treatment. This episode clearly introduced a new dynamic into the political process. It is believed that the controversy around the junta leader's candidacy contributed to the deterioration of the situation within and outside his support base. In fact, Guinea could no longer afford to have one military ruler replacing another after 24 years of brutal political repression and widespread poverty, the legacy of General Lansana Conté's regime. It was becoming increasingly clear that the junta was not prepared to hand over power and would resort to violence and electoral fraud to maintain itself at the helm of the state.

\section{DEMILITARISATION BY ELECTIONS}

The presidential elections that took place in Niger in January 2011 had the dual objective of ending the post-coup transition in the country and placing the democratisation process back on track. This was the second time a post-coup election had taken place with the aim of reviving the democratisation process.

The completion of the electoral process symbolised, in principle, the withdrawal of the military and the transfer of power to an elected civilian president. The presidential and legislative elections of 31 January 2011 followed a peaceful referendum on a new constitution, which was adopted in October 2010, and local elections, which were held on 8 January 2011.

The Constitution Council provided for ten candidates to contest the presidential election. They included, among others, Mahamadou Issoufou leader of the opposition PNDS; Mahamane Ousmane, former president, speaker of the National Assembly and leader of the Convention Démocratique et Sociale (Democratic and Social Convention - CDS); Seyni Oumarou; Mamadou Tandja, flag bearer of the discredited ruling party, the MNSD and Hama Amadou, a former prime minister under Tandja and leader of the newly created Movement Democratique Nigerien (Nigerien Democratic Movement - MDN). 
The results of the first round of what many observers believed was a relatively peaceful presidential contest gave an idea of the political and electoral map of the country. The PNDS took the lead, with 36.06 per cent, followed by the MNSD, with 23.24 per cent, while the newly formed MDN won 19.82 per cent and the CSD 08.42 per cent.

The run-off poll pitted Tandja against Issoufou, whose PNDS was a member of the 'Strategic Alliance', a group of 17 which included Hama Amadou's MDN and Mahamane Ousmane's CDS. Members of the alliance agreed to stand individually in the first round of the presidential election with a commitment to collectively endorse one candidate for the run-off. The initial intention was to prevent Senyi Oumarou, Tandja's representative, from winning the presidential race.

Two problems threatened the survival of the alliance. Firstly, Hama Hamadou contemplated joining the former ruling party to elbow out Issoufou. Secondly, there were fears that the two candidates with strong ethnic bases (Zerma for Issoufou and Hausa for Oumarou) might polarise the run-off.

However, the run-off proved beyond any shadow of a doubt that Niger's electorate is capable of transcending ethnicity in its voting behaviour and patterns. Issoufou performed relatively well in his opponent's Hausa ethnic stronghold, while Oumarou received votes in Issoufou's Zerma ethnic base. In addition, Oumarou, who lost the election, immediately conceded defeat and recognised the newly-elected president, while promising to play the role of a constructive opposition leader.

Thus Niger underwent a fairly successful transition through an electoral process in which the opposition leader was elected president with 58 per cent of the national vote. This epochal political development suggests that the process of demilitarisation and democratisation through elections is under way. How sustainable this trend is, only time will tell, as democratic reversals are possible, especially in volatile situations such as pertain in Niger.

Guinea's presidential election, unlike that in Niger, was marked by controversy and tension. It was also marred by violence, thereby exposing the fragmentation of the country along ethnic lines. Controversies around voter registration, the neutrality of the electoral commission and, mainly, the threat by General Sekouba Konate, the transitional president, to resign after the first round revealed the complexity of Guinea's political landscape and ethnic-based electoral tapestry.

Allegations of corruption resulted in the indictment and sentencing of Ben Sekou Sylla, head of the Commission electorale nationale independente (CENI). Despite all these challenges, the 2010 elections - the first credible elections in Guinea since 1958 - were hailed as relatively free and fair despite allegations 
of fraud made by two of the candidates, Sidya Toure (leader of the Union des Forces Republicain - United Republican Forces, UFR) and Lansana Kouyaté (Parti de l'Espoir et du Developpement National - Party of Hope and National Development, PEDN), among others.

CENI published provisional results after a 48-hour delay caused by technical issues and, indeed, the supreme court concluded that the electoral process had been tampered with in some areas and invalidated close to 900000 votes. As expected, the three main contenders in the presidential election of 27 June-Cellou Dalein Diallo, Alpha Condé and Sidya Touré - led the pack with 39 per cent, 20 per cent and 15 per cent of the vote respectively. According to Guinea's electoral laws if no candidate secures an absolute majority $(50 \%+1)$ it is necessary to hold a run-off.

The absence of an outright winner, therefore, meant that Diallo and Condé had to compete in a second round, held on 18 July. Condés first-round results took many by surprise. While he was expected to be the frontrunner because of his long history in the opposition, surprisingly, Diallo took the lead. Diallo's early success could be explained by two factors. The first was that the ethnic group he hails from, the Peulh, voted purely on ethnic lines. The second factor is the political harassment to which Diallo was subjected during the reign of Dadis Camara; harassment that may have endeared him to Guineans. His fortunes would, however, be reversed in the run-off.

It took the electoral commission almost three months to organise the runoff election due to sporadic violence that broke out and to doubts about the impartiality of the chairman of the commission. When the supreme court finally announced the results Condé had won with 52.52 per cent of the vote. Diallo received 47.48 per cent.

The election increased the ethnic polarisation of Guinea. One of the surprises was Condé's victory despite the fact that he had received only 20 per cent of the vote in the first round. Diallo was confident of his lead, particularly when the third-placed candidate, Sydia Touré, joined him, bringing with him 15\% of the electorate. This alliance, called 'Cellou Dalein Diallo President' also received the support of the former ruling parti, the Parti de l'unité et du progrès (PUP), led by Aboubacar Somparé.

But Condé's aim of forming what he called a 'rainbow coalition', bringing together 16 leaders and close to 90 small parties including François Lonsény Fall's Front uni pour la démocratie et le développement and Lansana Kouyatés Parti de l'espoir pour le développement national, helped him win the run-off. Not only did some of Touré's supporters abstain from following their leader's choice to vote for Dalein, high profile figures such as the mayor of Kaloum, an important city, defected to support Alpha Condé. Therefore, it could be argued that Condés 
first-round results did not reflect the reality of his support base. In addition, within the 900000 votes invalidated by the supreme court there were areas where Condé was the favourite. The run-off, therefore, was the opportunity to redefine campaign strategy, refine the alliance and expand to all regions in the country.

Condé's victory was not accidental. Indeed, many observers believed that Diallo had exhausted his electoral reservoir (predominantly Peulh) and could not move beyond his 46 per cent.

Cellou had assumed various ministerial positions during Lansana Conté's presidency and allegations of malpractice, perceived or real, compromised his chances of winning, a fact that nullified his argument of ethnic ostracism. While the electoral process in Guinea, like that in Niger, demonstrated some level of demilitarisation of politics it also contained a worrying ethnicisation. Evidence abounds on the African continent that the ethnicisation of politics and the politicisation of ethnicity is a deadly cocktail for democratisation (see Matlosa \& Zounmenou 2011).

\section{LESSONS OF EXPERIENCE}

Beyond the outcome of the presidential elections Niger's transition process took place in the context of fairly minimal international supervision. Unlike in Côte d'Ivoire, where a permanent consultative committee chaired by an ECOWAS representative was set up to oversee the process; or Guinea, where the transition process was marred by widespread acts of violence, in Niger the country's leaders had the confidence of their regional counterparts in their ability to return the country to a democratic path. This, in itself, was a risk. The country's food crisis had been politicised by President Tandja, who, on many occasions, publicly denied that there was one. According to several UN agencies, about 5-million people have so far benefited from food aid while over 220000 severely malnourished children under five are now out of danger (Parker 2009).

Guinea's post-coup transition was rescued by the assassination attempt on Captain Dadis Camara, with two major consequences. Firstly, the failed attempt revealed the profound internal contradictions within the junta, which was willing to perpetuate political violence as a strategy to remain in power. Camara's political ambitions and manoeuvres to hang onto power played a role in the massacre of opposition supporters. Secondly and most importantly, it undermined the junta's ability to manipulate the transition by providing an opportunity to the second in command, Sekouba Konate, to take up the leadership. General Sekouba himself underwent a surprising transformation from one of the most radical voices of the junta into a moderate figure whose neutral leadership was necessary for the transition. 
While officially opinions about the coups diverged, most observers, including regional leaders, saw in them a blessing in disguise. It is generally observed that the outcomes of a post-coup transition are unpredictable, complicated by personal ambition and fraught with security threats, as illustrated by that in Mauritania, where, in 2008, a dismissed army chief of staff, Mohamed Ould Abdel Aziz, immediately staged a coup against a newly elected president.

The peaceful transitions in Niger (under Salou Djibo) and in Guinea (under Sekouba Konate) have certainly shown some sense of domestic responsibility in responding to political crises. They also pose a challenge to leaders within the West African region who continue to undermine regional as well as domestic efforts to bring about peace and democratic governance.

There is now consensus that the newly-elected presidents will have to focus on the socio-economic challenges facing their countries. In Niger, while the Touareg insurgency might seem dormant if not defeated, the new authorities will need to take coherent steps against the threat posed by the army to the democratisation process.

In Guinea the army was the most important pillar of Lansana Conté's regime, which initiated, the so-called 'pact of army unity'. President Conté's control over the army was firm and his generosity to high-ranking officers helped him to limit the risk of being deposed through a military coup. At critical moments Conté lived in the camp with the soldiers in order to keep his eyes on them. He constantly reminded them about the necessity to stay united against 'civilian threat' and loyal to him, in the hope that they would avoid prosecution and would be able to take over after his departure (ICG 2007).

Niger's army is building for itself a reputation as a rescuer of the democratisation process. With the coups in 1999 and 2010 to restore democracy the army positioned itself as the guardian of the political process. Hopefully, the consensus that was built around the transition to give democracy a fresh chance will prevail and efforts will be made to strengthen national institutions, depersonalise politics and demilitarise society.

However, what is uncertain is whether or not military coups d'état have been jettisoned for good in both countries through robust institutional mechanisms and transformative leadership. In order to make coups a thing of the past, farreaching and wide-ranging security-sector reforms are key imperatives in both countries. Initiating security-sector reform is an urgent priority as the newly elected governments in both Niger and Guinea have already experienced one attempted coup each - in July 2011. 


\section{CONCLUSION}

The coup d'état in Niger against President Mamadou Tandja, and the abrupt exit of the Guinean junta leader, Moussa Dadis Camara, after he was wounded, rekindled in both countries the prospects for a transition to political order based on democratic norms. Though both crises were the result of political actors' resistance to the demands of their people and of the regional economic community, ECOWAS, they provided a further opportunity for the military to justify their continued involvement in national politics.

Niger and Guinea do not seem to be out of the woods yet. The army has become so entrenched in politics over the decades that both countries would need to complete security-sector reforms in order to restore civilian authority over the armed forces. One interesting feature of electoral politics in the two countries has been the politicisation of ethnicity and ethnicisation of politics by the political elite, a deadly cocktail which has, over the years, resulted in electoral violence.

The crises in Niger and Guinea give both ECOWAS and the African Union a platform from which to address seriously two main issues. The first of these is the problem of the legality and legitimacy of leadership. In confronting this issue regional bodies should take into consideration the conditions under which power is acquired, kept, exercised and transferred.

Should the legitimacy of leaders stem from hurriedly drafted and opportunistic laws or fraudulent elections, even if they are judged peaceful by observers? There are numerous cases in which leaders derive the 'legality' of their actions from manipulated laws and their legitimacy from fraudulent elections or coerced citizens. The legality and legitimacy of the political process should stem from the outcomes of inclusive multistakeholder consultation and citizen participation in order to ensure the credibility of a country's leadership.

The second issue relates to the role of the military in the democratic transformation process. If countries emerging from conflict and political crises undertook an effective reform of their security sectors many difficulties would be avoided. The cases of Guinea and, more recently, Niger, display a disturbing pattern of the army as the guardian of the political reform process, with compromised and sometimes violent outcomes. This should serve as a warning to other African leaders who may want to cling to power against the will of their people. The ECOWAS Additional Protocol contains principles and rules governing the relationship of the security forces with government and their involvement in politics (ECOWAS 2001).

One may argue that the legal and political environment for the full implementation and enforcement of the Additional Protocol already exists now that it has been ratified by 10 of the 15 member states. ECOWAS and African 
leaders need more than a declaration to reiterate their commitment to strengthen good governance through effective institution-building, respect for the rule of law and commitment to socio-economic development. The risk of instability is even greater if the army intervenes in a partisan manner during moments of political crisis.

\section{- REFERENCES}

Akindes, F. 2004. The Roots of the Military-Political Crises in Côte d'Ivoire. Research Report No.128. Uppsala: Nordic Africa Institute, Sweden.

AUC. 2007. African Charter on Democracy, Elections and Governance. Addis Ababa, Ethiopia.

- 2010. Election-Related Disputes and Political Violence: Strengthening the Role of the African Union in Preventing, Managing and Resolving Conflict. Addis Ababa, Ethiopia.

—. 2011. Report of the Experts Group on Côte d'Ivoire Post-election Crisis. Addis Ababa, Ethiopia.

Bah, A. 2010. 'Democracy and civil war: Citizenship and peacemaking in Côte d'Ivoire'. African Affairs 109(437).

Bangoura, D. 1992. Les armées africaines (1960-1990). Paris: Cheam.

Baudais, V \& G Chauzal. 2010. 'The 2010 Coup D'état In Niger: A Praetorian Regulation Of Politics?'. African Affairs 110 (439), March.

Collier, P. 2005. Coup Traps: Why does Africa have so many Coups d'Etat? Centre for the Study of African Economies, University of Oxford.

—. 2009. Wars, Guns and Votes: Democracy in Dangerous Places. London: The Bodley Head.

Coleman, J S \& B Brice.1962.' The Role of the Military in Sub-Saharan Africa'. In J J Johnson (ed). The Role Of The Military In Underdeveloped Countries. Princeton: Princeton University Press.

Commission Electorale Independente (CEI). 2010. Le Code Electoral de la Côte d'Ivoire. Abidjan, Côte d'Ivoire.

Constitution of Niger. 1999.

Diallo, A \& T Z Suifon. 2008. 'Coup D'état: Its Inevitability, Legitimizing Factors \& Lessons For Africa'. WANEP Policy Brief, Abuja, Nigeria.

ECOWAS. 2001. ECOWAS Protocol on Democracy and Good Governance.

—. 2009a. Communiqué N 081/2009, 24 August.

- 2009b. Final communiqué of the Extraordinary Summit Of Ecowas Heads Of State And Government. Abuja, 17 October.

Decalo. S. 1976. Coups and Army Rule in Africa: Studies in Military Style. New Haven, London: Yale University Press. 
Deger, S. 1986. Military Expenditure In Third World Countries. London: Routledge. European Union. 2011. 'Elections Présidentielles du 31 Octobre au 28 Novembre 2010'. Rapport Final. Brussels, Belgium, February.

Human Rights Watch. 'Guinea: 28 September Massacre was Premeditated'. Available at: www.hrw.org/en/news/2009/10/27/guinea-september-28-massacrewas-premeditated

Huntington, S. 1994. The Third Wave: Democratisation in the Late Twentieth Century. Oklahoma: University of Oklahoma Press.

Hutchful, E \& A Bathily (eds). 1998. The Military and Militarism in Africa, Dakar: CODESRIA Books.

International Crisis Group (ICG). 2009. 'Les Imperatifs de Sortir de Crises'. Africa Report 62. Brussels, Belgium.

Jeong, H. 2005. Peacebuilding in Postconflict Societies: Strategy and Process. Boulder: Lynne Rienner.

Kanyinga, K \& D Okello (eds). 2010. Tensions and Reversals in Democratic Transitions: The Kenya 2007 General Elections. Nairobi: Society for International Development.

Kieh, G Klay \& PO Agbese. 2005. The Military and Politics in Africa: From Engagement to Democratic and Constitutional Control. London: Asgate.

Kirwin, M. 2006. 'The Security Dilemma and Conflict in Côte d'Ivoire. Nordic Journal of African Studies 15(1).

Lindberg, S. 2006. Democracy and Elections in Africa. Baltimore: The Johns Hopkins University Press.

—. 2009. 'Democratisation by Elections: A Mixed Record'. Journal of Democracy 20(3), July.

Matlosa, K. 1998. ' Military Rule and Withdrawal from Power: The case of Lesotho'. In E Hutchful \& A Bathily (eds). The Military and Militarism in Africa. Dakar: CODESRIA Books.

— , G Khadiagala \& V Shale (eds). 2010. When Elephants Fight: Preventing and Resolving Election-Related Conflicts in Africa. Johannesburg: EISA.

_ \& D Zounmenou. 2011. 'Identity, Diversity and Electoral Violence: Dilemmas of Democratic Transformation in Africa'. Africa Review 3(2).

Mazrui, A. 1996. ' Democracy and Regional Stability in the Pan African Agenda'. In CODESRIA, Pouvoir et paix civile en Afrique. Présence Africaine.

Mbembe, A. 1990. 'Pouvoir, Violence et Accumulation'. Politique Africaine 39(725).

Mc Gowan, P \& T H Johnson. 1984. 'African Military Coup d'Etat And Underdevelopment: A Quantitative Historical Analysis'. The Journal of Modern African Studies 22(4).

Muhlberger, S \& P Paine. 2000. Is There a History of Democracy? New York: The Chivalry Bookshelf. 
Omoigui, N. 2004. Military Defence Pacts in Africa. Cited in N Ngoma. 'Coups And Coup Attempts In Africa: Is There A Missing Link?’ Africa Security Review 13(3). Pretoria, South Africa.

Parker, L. 2009. 'Aid agency warns of "double disaster" for Niger'. Available at: www. nigerfoodrelief.org/hot-news 1/aidagencywarnsofdoubledisasterforniger

Sorensen, G. 2008. Democracy and Democratisation: Processes and Prospects in a Changing World, 3rd edition. Boulder, Co: Westview Press.

Souare, I. 2009. 'The AU and the Challenge of Unconstitutional Change of Governments in Africa'. ISS Paper 197, August, South Africa.

— \& P-S Handy. 2009. ‘Guinée, Bon Coup, Mauvais Coup: les Errances d'une transition qui peut encore reussir'. ISS Paper No 195, October, Pretoria, South Africa.

Souare, K (ed). 2006. Civil wars and coups d'état in West Africa: An attempt to understand the roots and prescribe possible solutions. Lanham, MD: University Press of America.

Tolou, L. 2010. 'Elections de la peur ou peur des elections? Dilemme et contretemps de la sortie de crise en Côte d'Ivoire'. In R Bowd \& A Chikwanha (eds). Understanding Africa's Contemporary Conflicts: Origins, Challenges and Peacebuilding. Pretoria: Institute for Security Studies.

UNSC. 2004. Resolution S/ RES / 1528, Adopted by the Security Council at its 4918th meeting, 27 February.

—. 2011. Resolution S/RES / 1975, Adopted by the Security Council at its 6508th meeting, 30 March.

Zounmenou, D D. 2008. 'Cote d'Ivoire Elections: Is There Hope?' Africa Security Review 17(2). Institute for Security Studies, June.

—. 2009. 'Côte d'Ivoire: Whose election is it anyway?' ISSTODAY. Institute for Security Studies, 5 November.

— . 2011. 'Côte d'Ivoire Post-Electoral Conflict: What Is At Stake?' Africa Security Review 20(1), March.

_ \& \& Motsamai. 2011. 'Cote d'Ivoire: Now it's Gbagbo vs the AU'. ISSMagazine, April/May.

_ \& P S Handy. 2011. 'Côte d'Ivoire: Let Them Vote Again'. ISSMagazine, February/March. 